\title{
CONSTRUCTION SOLUTIONS FOR HISTORICAL OBJECT FOUNDATIONS IN THE CONTEXT OF CHANGING THEIR FUNCTIONAL USE
}

\author{
Kazimierz GWIZDAŁA ${ }^{1}$, Sylwia FLORKOWSKA ${ }^{2}$ \\ Gdańsk University of Technology, \\ Civil and Environmental Engineering, Gdańsk, Poland
}

\begin{abstract}
Properly executed renovation and adaptation of a grade listed property not only ensures its constructional safety, but may also highlight the object's historical value. Taking into consideration various factors, such as divergence of interests, or technical and legal determinants, it is safe to say that the renovation and adaptation of grade listed properties for new purposes is a complex process. The authors of the paper wish to discuss the problem of renovation based on selected properties, with special regard to constructional solutions for foundations. The presented examples will illustrate the issue of foundation enhancements resulting from the adaptation of buildings for new purposes. Through individual constructional solutions, such as jet grouting, it was possible to ensure the stability of degraded properties and safe transfer of increased values of usage load.
\end{abstract}

Keywords: renovation, adaptation of grade listed properties, arcade houses, reinforcement of foundations, jet grouting

\section{INTRODUCTION}

Adapting historical monuments to serve a new function is a common phenomenon nowadays. With the exception of sacral buildings, a large part of historical buildings have lost their original functions, thus many renovation

\footnotetext{
${ }^{1}$ Corresponding author: Gdańsk University of Technology, Civil and Environmental Engineering, Narutowicza st 11/12, 80-233 Gdańsk, e-mail: kgwiz@pg.gda.pl, tel.+48583471132

2 e-mail: sylflork@pg.gda.pl
} 
works currently carried out on such buildings are connected with adaptive intervention. Properly carried out renovation and adaption of a historical building ought to ensure the safety of its construction and, at the same time, be carried out in such a way that emphasizes its historical form and value. The authors of the work hope to discuss the problems and aspects connected with the renovation of selected grade listed properties, with particular attention given to constructional solutions for foundations.

\section{EXAMPLES OF REINFORCING FOUNDATIONS OF ADAPTED HISTORICAL BUILDINGS}

\subsection{Arcade house in Gdańsk Orunia}

An example of a project involving works connected with reinforcing the foundation is the renovation of an arcade house in Gdańsk Orunia. The building was constructed in 1800, and originally served as a workshop and forge; in the XX century, it was converted into a residential dwelling. In 2012, works which aimed to completely renovate the building as well as adapt it to serve a new function were assumed [1]. The existing brick-stone foundations of the building were found to be in a satisfactory technical condition, and required only moisture protection. However, due to the introduction of new construction elements and changes in static and service load, it was necessary to construct new foundations. Favorable subsurface and groundwater conditions made it possible to construct direct foundations in the form of reinforced concrete strips. The works were carried out using the method of reinforcing in segments, after first loading and supporting the construction of the building along the foundations.

\subsection{Arcade house in Marynowy}

A similar solution (in the form of introducing a new direct foundation) was applied during the renovation of a XIX-century arcade house in Marynowy. One of the assumptions of the renovation project for the building was maintaining the original spatial layout of the rooms while allowing them to be used for residential and public utility purposes. Due to the anticipated higher values of service loads and bad technical condition of the arcade construction, it was necessary to reinforce it. Upon analyzing the soil conditions and carrying out static-strength calculations for the construction of the house, it was decided that a foundation in the form of reinforced concrete strips will be made beneath the construction of the destabilized arcade. A stone pedestal was placed on the 
foundation structure, on which the repaired and reinforced load-bearing posts of the arcade were placed.

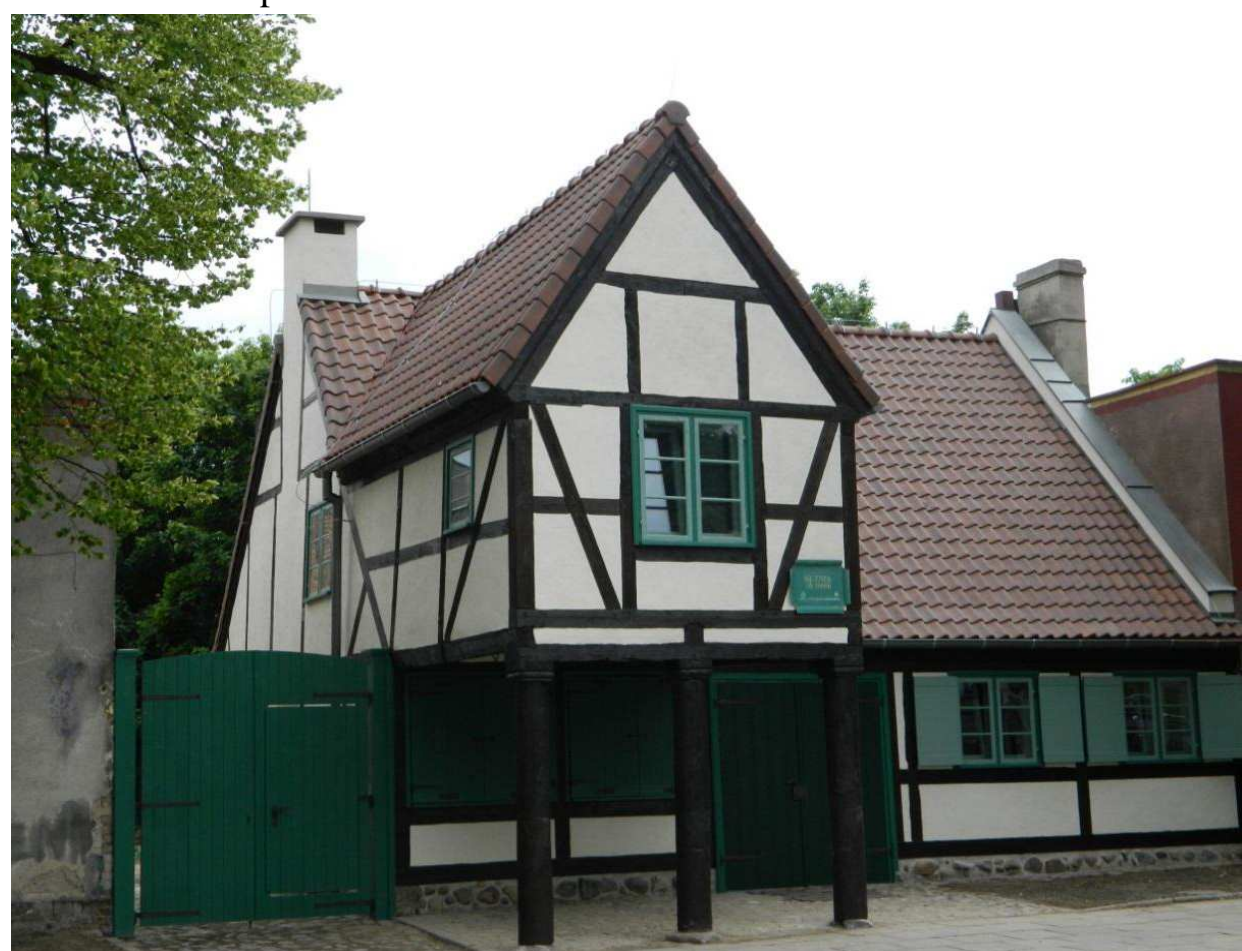

Fig. 1. Forge building after completion of construction-conservation work

\subsection{Dwór Młyniska in Gdańsk}

A different constructional solution for foundations was accepted during the course of renovating and adapting the Młyniska Manor building in Gdańsk, the construction of which dates back to 1779 . Over the years, this building served a residential function; in 1813, it burnt down and was rebuilt in a classicistic style in 1820. Młyniska Manor survived World War II in good condition and was divided into dwellings. In the 70's, it was placed under the charge of a conservator; however, over the course of time, it was largely destroyed and its structure damaged. In 1998, the building was subjected to major renovation and added onto [5].

Before assuming works it was established that the building is placed on brick foundation walls $60 \mathrm{~cm}$ in width, without strip footing. The depth of the foundation ranged from 20 to $90 \mathrm{~cm}$ beneath the existing basement floor, in the backfill layer. 


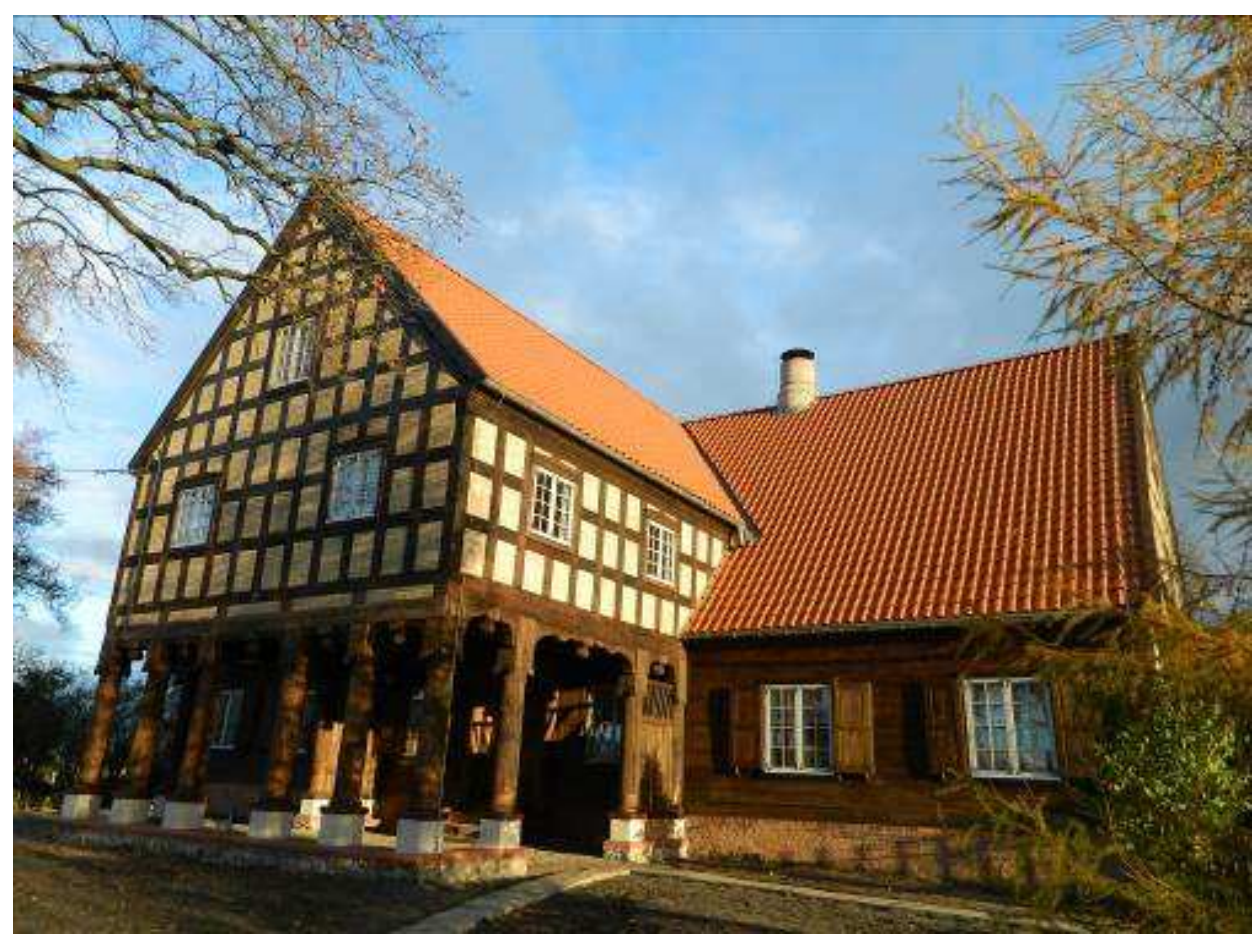

Fig. 2. Arcade house in Marynowy upon completion of building-conservation works

The foundations were in a bad technical condition, on poor soil, which resulted in the cracking of the foundation walls and significant settlement of the building. Originally, new reinforced concrete strip foundations were designed, supported by prefabricated reinforced concrete wells measuring $1.0 \mathrm{~m}$ and 1.2 $\mathrm{m}$ in diameter, reaching the layer of load-bearing sands - a very difficult and problematic solution for the contractor, especially when accompanied by a high level of groundwater. Ultimately, the entirety of works connected with strengthening the foundations were carried out using jet grouting technology, which is based on making soil-cement columns crowned with a reinforced concrete cap.

The soil reinforcement process with the application of high-pressure jet grouting is based on destroying the natural structure of the soil with a stream of grout slurry (usually cement-based) introduced into the soil environment with high energy. The applied operating pressure of $50 \mathrm{MPa}$ and velocity at which the grout flows out of the jet nozzle (approximately $100 \mathrm{~m} / \mathrm{s}$ ) results in the separation of soil fragments and them becoming mixed in with the introduced grouting slurry. Over the course of the injection, the upward lifting of the drill pipe in connection with the simultaneous rotating movement results in the 
formation of jet grout columns within the ground. The lighter fractions are washed out along the injection pipe, onto the land surface, creating a technological material which is removed and most often treated as postproduction waste. The soil-cement mixture reaches significant strength values upon setting, comparable to those of concrete.

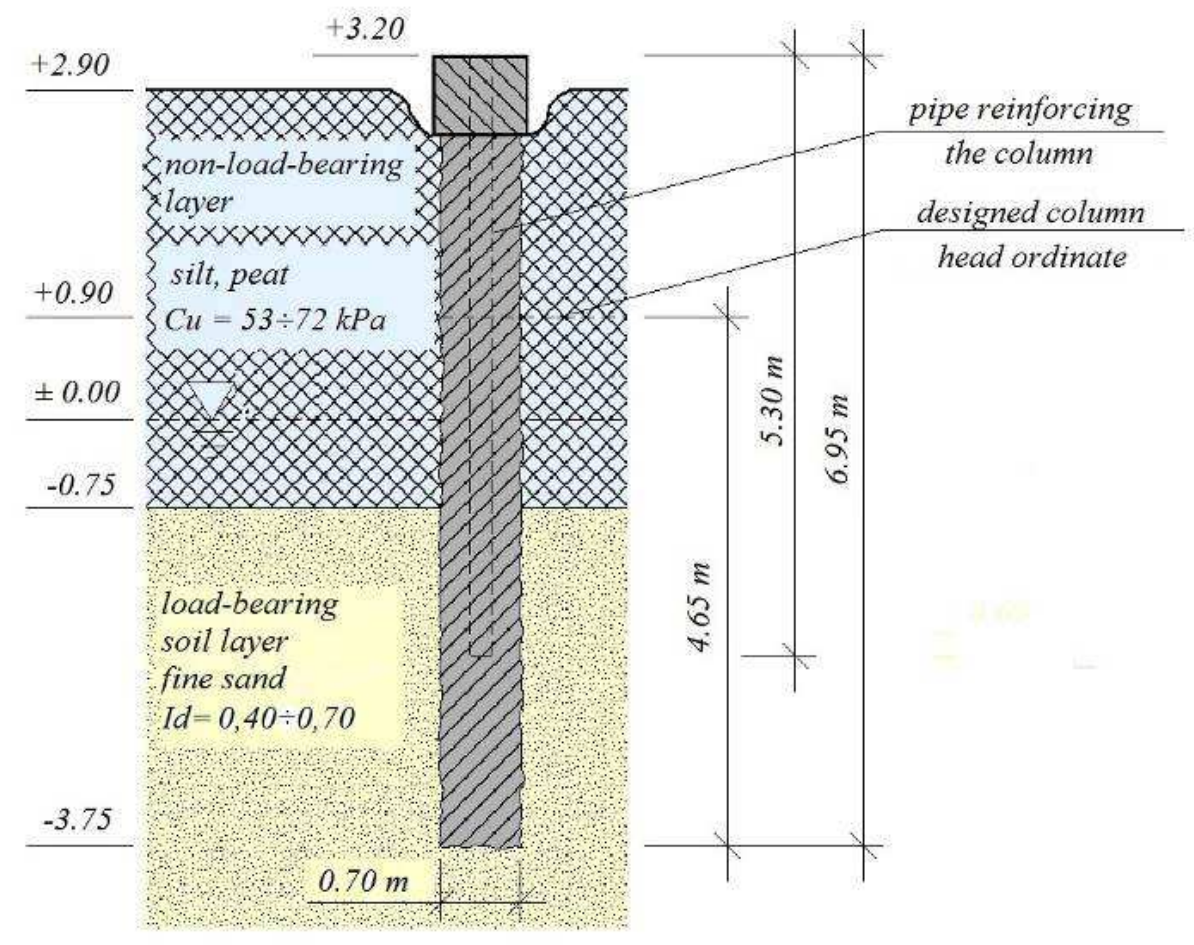

Fig. 3. Geotechnical cross-section of soil along with the jet column

The impact range of the cutting stream depends on the type of soil as well as the applied technological variant [2]. When the soil-cement sets, adequate strength parameters are obtained, falling within the range of $1 \mathrm{MPa}$ to $25 \mathrm{MPa}$, depending on the type of soil and content of cement in the mixture. As a result of applying additives (e.g. betonite), it is possible to obtain increased waterproof qualities of the soil-cement material.

Over 40 vertical and inclined jet grout columns, crowned with reinforced caps, were formed beneath the discussed Młyniska Manor building. The diameter of a single column was $0.7 \mathrm{~m}$, whereas their length ranged from 4 to $6 \mathrm{~m}$ depending on the applied load and depth of the load-bearing sand layer. 


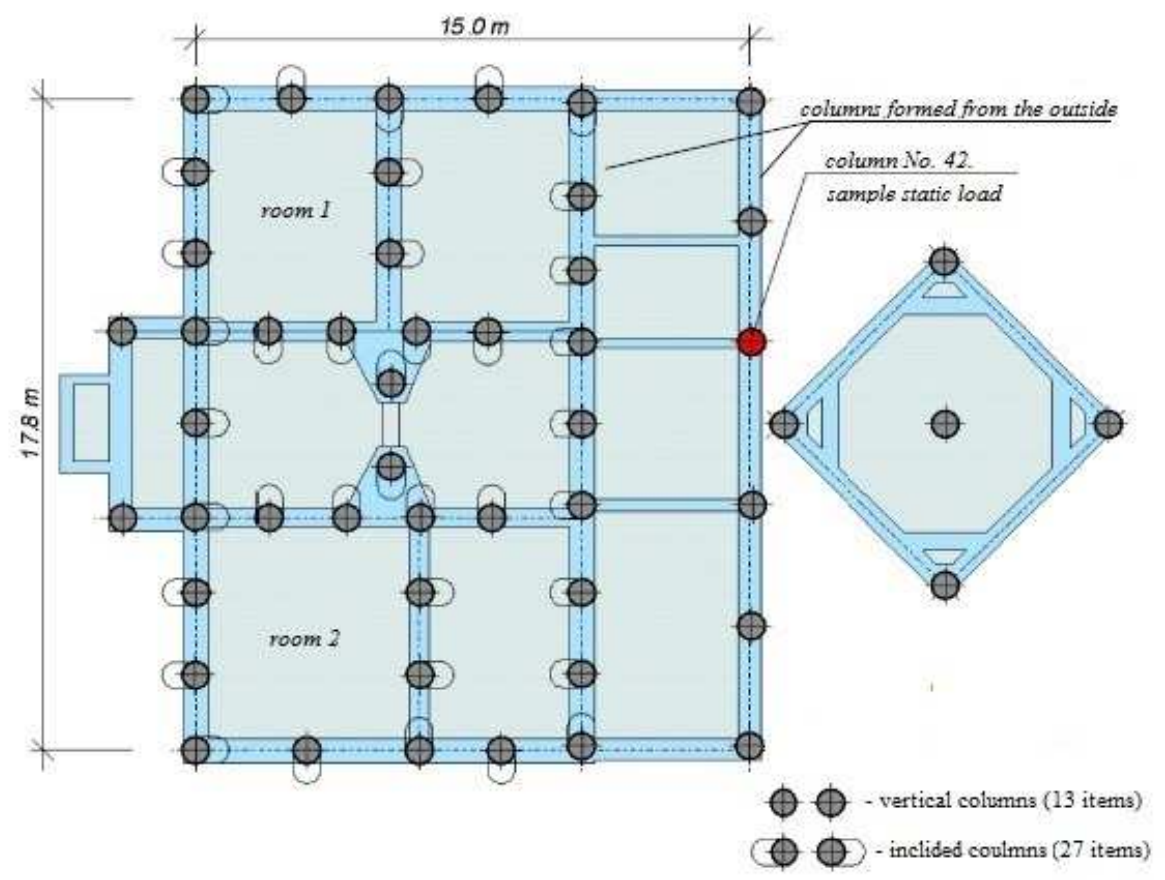

Fig. 4. Layout of columns beneath Młyniska Manor building [3]

The inclination of the outside columns was $8: 1$, whereas in the case of inside ones - 10:1; however, the directions in which they were inclined varied in order to ensure adequate stiffness and behavior of the entire column group. The proper inclination of columns ensured relatively easy execution, i.e. the machine was placed only in two inside rooms (1 and 2), as shown in Fig. 4. The jet grouting was carried one using mono-jet technology, at a pressure of approximately $50 \mathrm{MPa}$. A grout slurry was made of portland cement 35 , the total of which amounted to $3250 \mathrm{dm}^{3}$. The rotation speed of the jet rod was 20 rotations/min., whereas the withdrawal velocity was $4 \mathrm{~cm} / 10 \mathrm{sec}$. [2]. An additional test column was made in the neighborhood of the strengthened building, which was used to verify the load-bearing capacity of columns accepted in the reinforcement project (Fig. 5). The settlement of a single column for the design load of $\mathrm{Q}_{\mathrm{r}}=600 \mathrm{kN}$ was under $3 \mathrm{~mm}$.

Thanks to the applied technology, it was possible to restrict the settlement of the building, as well as stabilize the construction. Applying column foundations ensures high rigidity of the support and the reduction of section forces in existing buildings. The created jet grout columns made it possible to carry increased loads over to deeper, load-bearing layers of the soil (Fig. 3). 


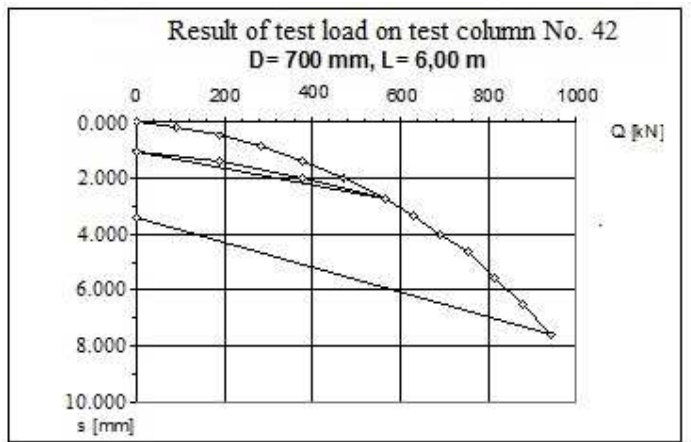

Fig. 5. "Młyniska Manor" - results of test load on test column [2]

Moreover, as a result of inclining the columns in various directions and crowning them with a reinforced concrete cap, it was possible to obtain stiffness of the foundation construction. An advantage of the technology is surgeless drilling and applying small diameters of boreholes, thanks to which it is especially useful when reinforcing the foundations of grade listed buildings. Fig. 6 shows Młyniska Manor after completion of construction and conservation works.

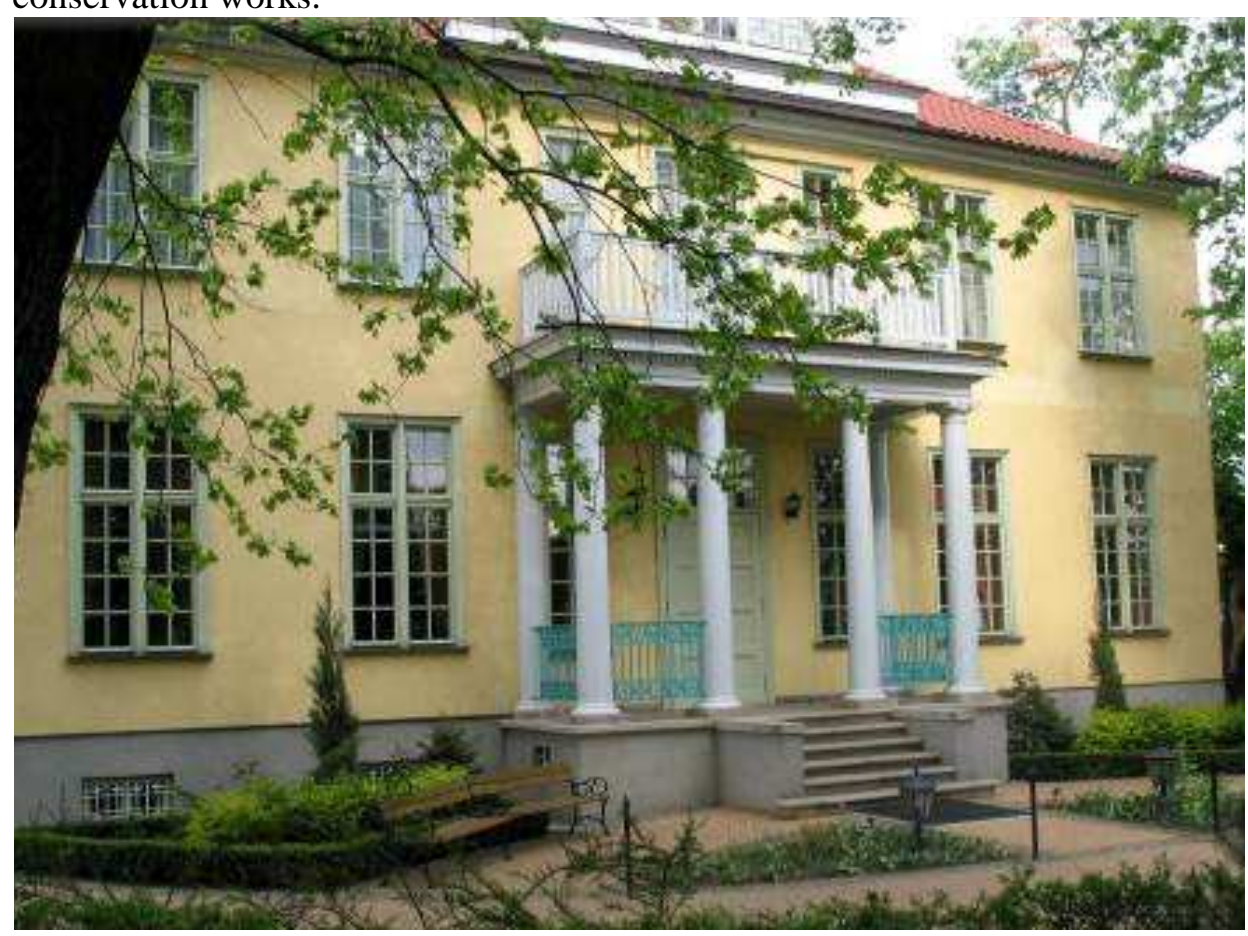

Fig. 6. Młyniska Manor after completion of construction-conservation works 


\section{CONCLUSIONS}

Based on the presented realizations, it can be stated that in the case of repairing the structures of grade listed buildings, one cannot indicate a single, correct repair method.

From the conservation point of view, it is most beneficial to interfere in the historic structure as little as possible, taking advantage of the existing structural elements. The condition in which the historic construction has been maintained and planned changes regarding its functional use, however, force designers and contractors to apply various solutions, individually adapted to the given object. The renovation of a listed building requires an individual approach every time, as well as verification of earlier accepted solutions at subsequent stages of the work process. The lack of possibility to apply methods which are highly invasive to the historic structure at the design stage makes it so that the originally accepted solutions are often changed over the course of carrying out construction-conservation works. This is in agreement with the currently applied "observation method" contained in Eurocode 7, [4]. In two of the presented realizations, a solution in the form of introducing a new construction element was applied. In the case of renovating the Młyniska Manor building, using the jet grouting technology turned out to be the most advantageous solution. Due to surgeless drilling and applying small diameters of boreholes, jet grouting technology works especially well when strengthening the foundations of grade listed properties. In each case, the decisions made were based on carried out static-strength analyses, analyses of geotechnical conditions and consultations with a conservator. Thanks to the works carried out, it was possible to obtain the required stability of the construction, reduce excessive settlement and safely carry increased service loads onto load-bearing soil.

\section{REFERENCES}

1. Barański M.: Program funkcjonalno- użtkowy. Budowa Centrum Aktywizacji i Innowacji Kuźnia, Gdańsk, 2011.

2. Gwizdała K., Kościk P.: Zastosowanie iniekcji strumieniowej do wzmacniania posadowień istniejacych obiektów budowlanych, International Workshop: City of tommorow and cultural heritage. Pomerania outlook, Gdańsk, 2005.

3. Gwizdała K., Tejchman A., Brzozowski T.: Underpinning of the foundations of „Dwór Mtyniska” in Gdańsk, International Workshop on rehabilitation of existing urban building stock, Gdańsk, 17.06-19.06.2004. 
4. PN-EN 1997-1:2008-Eurokod 7- Projektowanie geotechnicze; część 1: Zasady ogólne.

\title{
ROZWIAZZANIA KONSTRUKCYJNE POSADOWIEŃ OBIEKTÓW ZABYTKOWYCH W KONTEKŚCIE ZMIANY ICH FUNKCJI UŻYTKOWEJ
}

\begin{abstract}
Streszczenie
Prawidłowo przeprowadzona renowacja i adaptacja obiektu zabytkowego powinna zapewnić bezpieczeństwo konstrukcji, a jednocześnie podkreślić jego historyczną formę i wartość. Niejednokrotnie wybór rozwiązania konstrukcyjnego bywa kłopotliwy, ze względu na rozbieżność interesów inżyniera, konserwatora i inwestora. Biorąc pod uwage uwarunkowania techniczne, funkcjonalne oraz prawne, realizacja prac związanych z renowacją i adaptacją obiektów zabytkowych ma charakter złożony. Decyzja o renowacji bądź wymianie wybranych elementów konstrukcyjnych w każdym przypadku powinna być poprzedzona kompleksową analizą techniczną oraz uzgodnieniami konserwatorskimi. Autorzy referatu omówili problematykę i aspekty renowacji w wybranych obiektach zabytkowych, ze szczególnym uwzględnieniem rozwiązań konstrukcyjnych fundamentów. Przedstawiono wzmocnienia posadowień obiektów wynikające ze zmiany ich funkcji użytkowej. W omawianych przypadkach przyjęto rozwiązania w postaci wprowadzenia nowych elementów konstrukcyjnych oraz wzmocnienia istniejących fundamentów przy użyciu technologii iniekcji strumieniowej. Dzięki przyjętym rozwiązaniom udało się zapewnić stabilność zdegradowanych dotąd obiektów oraz bezpieczne przeniesienie zwiększonych wartości obciążeń użytkowych, jak również ograniczyć nadmierne osiadania obiektu.
\end{abstract}

Słowa kluczowe: adaptacja, renowacja obiektów zabytkowych, wzmacnianie fundamentów, iniekcja strumieniowa

Editor received the manuscript: $12.01 .2015 \mathrm{r}$. 
